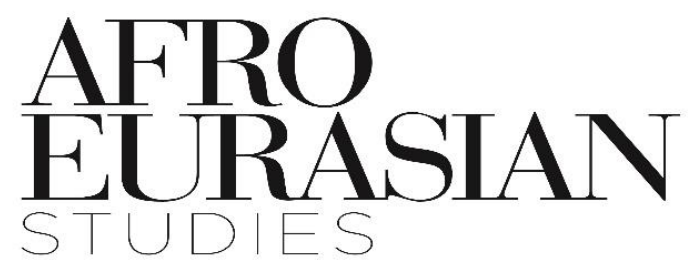

[AFES], 2019, 8 (1): 39-54

\title{
The Analysis of the Effect of Real Interests on Income Distribution with ARDL Model Approach
}

Ahmet KAMACI
Asst. Prof., Bartin University Faculty of Economics and Administrative Sciences
Administrative Sciences,
akamaci@bartin.edu.tr, Orcid Id: 0000-0002-7858-6131
M. Said CEYHAN
Asst. Prof., Bartin University Faculty of Economics and Administrative Sciences
Administrative Sciences,
sceyhan@bartin.edu.tr, Orcid Id: 0000-0002-0310-8207
Mehmet Akif PEÇE
R.A., Bartin University Faculty of Economics and Administrative Sciences
Administrative Sciences,
apece@bartin.edu.tr, Orcid Id: 0000-0002-2870-5008

Article Information

Article Types : Research Article

Received : 25.02 .2019

Accepted : 28.03.2019

Published : 28.03.2019

Pub Date Season: March 2019

Cite as: KAMACI, A, CEYHAN, M, PEÇE, M. (2019). The Analysis of the Effect of Real Interests on Income Distribution with ARDL Model Approach. Afro Eurasian Studies, 8 (1), 39-54. Retrieved from http://dergipark.gov.tr/afes/issue/44214/531908

Plagiarism: This article has been reviewed by at least two referees and scanned via a plagiarism software.

Copyright (C) Published by MUSIAD- Ataköy 7-8-9-10 Mah. Cobancesme E5 Yanyol Cad. No:4 Bakirkoy, 34158 Istanbul / Turkey Tel +90 (212) 3953302 Fax +90 (212) 3950001 aestudies@musiad.org. 


\title{
The Analysis of the Effect of Real Interests on Income Distribution with ARDL Model Approach ${ }^{1}$
}

\begin{abstract}
The Gini coefficient which measures the unfair distribution of income is a value between 0 and 1 . As the index value approaches to 1, unfairness increases and as it approaches to 0 , income distribution becomes fairer. The aim of this study is to examine the effect of real interest on income distribution in 5 developing countries which are close to each other in terms of real per capita income with panel data analysis. In this context, since the data of 2000-2016 include cross sectional dependency, second generation panel root tests were used. Since the series are stable on different levels, ARDL model was utilized. Then, the coefficient between the variables were determined by using the PMG estimator and causality analysis was conducted. According to the result of the study, although there isn't a short-term relationship between the variables, there is a cointegrated relationship in long-term. Furthermore, according to the PMG estimator, an increase of 1 unit, increases the Gini coefficient by 0.007 . Since the conducted causality analysis was resulted in accordance with the Gini coefficient from real interests, it verifies this result. Since the increase in real interests increases the Gini coefficient, real interests should be decreased for a more fair income distribution, according to the result of this study.
\end{abstract}

Keywords: Real interest, fair distribution of income, Gini coefficient, ARDL model, PMG estimator.

\footnotetext{
${ }^{1}$ This study is an expanded version of the presentation which was presented in "International Congress on Economic Researches and Financial Markets-IERFM" congress, held by Nişantaşı and Trakya University on May 12-13, 2017 and titled as "The Relationship of Real Interest and Income Distribution: An Examination on Developing Countries".
} 


\section{Introduction}

Real interests are calculated by using the $1+$ nominal interest rate $\div 1+$ inflation rate equation (Ceyhan, 2004:34). Real interest phenomenon defines the inflation-adjusted nominal interests. As it shows the net interest, independent from the effects of the inflation, the real interest rates have great importance in economies. When considering the interest rates that are paid in return to used savings, calculating interest rates again on real basis would give more accurate results. Real interests are key variables in many theoretic models of macroeconomics. These models can be stated as, consumption-oriented asset pricing model, models that determine the policies of Central Bank, Neoclassical growth model and monetary transmission mechanism (Yurttagüler and Kutlu, 2003:209). A decrease in the economic growth, increases real interests. If the real interests are higher than the economic growth rate, it is necessary to refund in order to finance the increasing rates (Ceyhan 2004:35,45). Since interest payments are performed as transfer payments made for people who loan money to the state, it directly affects the unfair distribution of income. Since the people who loan money to the state are wealthy, interest payments cause flow of funds from poor to rich people. For this reason, interest payments that are performed for internal debts, increase the distribution of income (Ersezer, 2006:265). Since the inflation would increase as the interests increase, there would be a decrease in labor productivity. Because there is an inverse relationship between productivity and inflation, the increase in productivity would decrease the real interest rates by decreasing the inflation (Kamac1, 2016:324).

Real interests are calculated as inflation-adjusted in Turkey. In Graphic 1, the course of the real inflations in Turkey for the discussed periods were given. 
Graphic 1: Real Interests in Turkey (2000-2016)

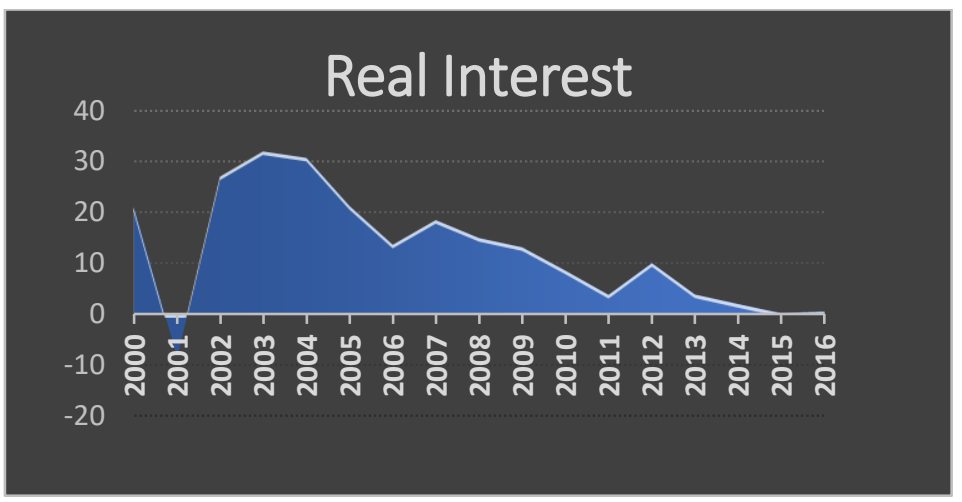

Source: IMF (Nominal interests that are taken from IMF were calculated by the researchers).

According to Graphic 1, real interests reached to maximum level in 2003. Then it dropped to below 1 by the year 2016 with a rapid decrease. The lowest level of real interests was observed in the crisis of 2001 with -8.5 .

Income equality is one of the unresolvable fundamental problems in world economies. Since the income distribution could not be distributed fairly among the societies, developing countries could not reach the life standard of developed countries. The criterion that shows the fair distribution of income among the societies and how fair it is distributed is the data that demonstrates the inequality of income (Çalışkan, 2010:89). Income distribution can be shortly defined as the distribution of national income which is produced in a certain country in a certain period among the individuals or production factors. It is calculated with Lorenz curve or the Gini Coefficient which is obtained from Lorenz curve. In Turkey, income equality is calculated with the Gini coefficient. The Gini coefficient is between 0 and 1 . As it approaches to 1 , the inequality increases and as it approaches to 0, the inequality decreases. In Graphic 2, the Gini coefficient in Turkey for the discussed periods are given. 


\section{Graphic 2: The Gini Coefficient in Turkey (2000-2016)}

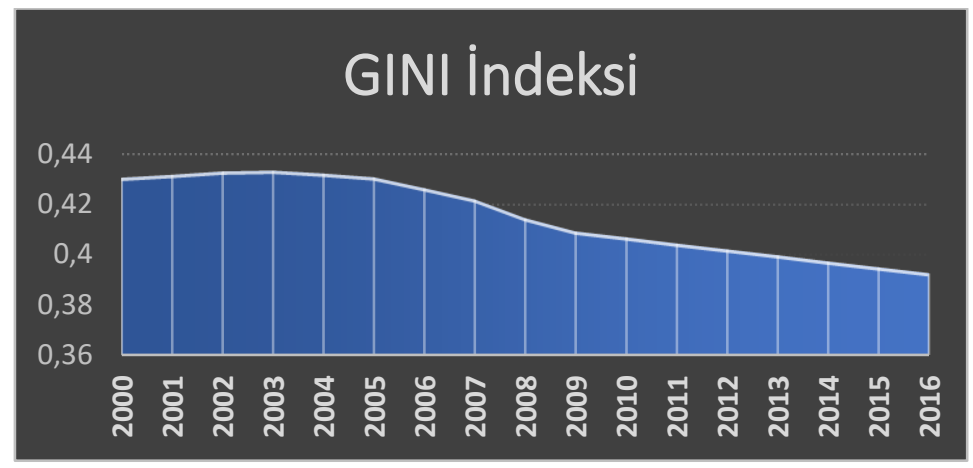

Source: https://dataverse.harvard.edu/dataset

According to Graphic 2, decreases are observed in the Gini coefficient after 2002 in Turkey. Although these decreases are small, it can be stated that there are improvements in the fair distribution of income in Turkey.

Plenty of factors are stated in the literature that cause inequality of income. The effect of real interest rates on the inequality of income in terms of interest payments is one of these factors.

In the next section of the research, the relationship between the real interests and income distribution will be determined with econometric model by conducting literature survey.

\section{Literature Survey}

In the academic literature, there are limited number of researches that examine the relationship between the real interest rate and income distribution. The reason for this is the difficulty of calculating the real interest rate and the difficulties of obtaining the Gini coefficient. For this reason, the direction of the relationship was determined by adding variables to the literature survey such as nominal interest rate, consumption and foreign exchange rate. 
In their study, Campbell and Mankiw (1989), examined the relationship of consumption, income and interest rates. The sample group consists of the quarterly data of USA between 1953:Q1 and 1986:Q4. According to result of the research of which regression analysis was conducted, a strong relationship was determined between income and consumption. An increase of $1 \%$ in income, increases the consumption by $0.5 \%$. Furthermore, they reached the result that, expected real interest rates are not related to the expected consumption change.

Grüner (2001), examined the relationship between distribution of wealth and interest rate. In this study, which discusses the situation in USA, different time periods were chosen (1911-1983, 1947-1991, 1831-1997). According to the result of the research of which regression analysis was conducted, there is a positive relationship between the real interests and inequality of income. Another result of the research is that the increase in interest rate, restricts the loan demand.

In their study, Sever and Mizrak (2007) examined the relationship of foreign exchange rate, inflation and interest rates. This study which was conducted in Turkey for the periods between 1987:01 and 2006:06 by using monthly data, was tested with VAR analysis. As a result of the research, it was observed that the increase in interest rates leads to impairments in income distribution. They also reached the results that the increase in interests increase the foreign exchange rate and inflation.

Demir and Sever (2008) discussed the relationship of domestic debt, interest rate and income distribution in Turkey for the period of 1987-2007. According to the result of the research of which cointegration and causality analysis were used, domestic debt, capital and interest payments increase the unfair distribution of income.

Çetin (2013) calculated the contributions of factor incomes and transfer incomes to the inequality within the frame of total disposable income between 2002 and 2009 in Turkey by using the data of TSI and Shorrocks Decomposition Analysis. As a result of the study, it was determined that the biggest share in the 
impairments of income equality among factor incomes in Turkey is interest incomes.

In their study, Saymeh and Orabi (2013) examined the effect of interest rates on economic growth. This study in which the data of Jordan for the years of 20002010 were used, were examined with cointegration and causality analyses. According to the result of the study, there is a strong relationship between the nominal interest rate and economic growth.

Shrivastava et al. (2013) examined the effect of real interests on investment and economic growth for the period of 2000-2011 in 24 sectors of India. According to the result of this study of which panel data fixed effects model was used, an increase of 100 points in real interest rates, decreases non-agricultural GDP by 20-23 points.

Lancastre (2016) examined the inequality of income with real interest rate for the period of 1985-2005 in the USA. According to the result of the study of which input-output analysis was used, decreases in real interest rate, increase the inequality of income.

Maraşlı (2016) reached the result that real interests impair unfair distribution of income in his study which was conducted on a total of 77 countries with different groups in Latin America, developed and developing countries and worldwide by using panel data analysis method.

In another study conducted by Sugözü et al. (2017), the relationship between interest rates and income distribution for the period of 2002-2015 in Turkey was examined. In this study of which TOPSIS method was used, it was determined that interest payments on domestic debt and interest rates impair the fair distribution of income.

As it can be seen from the literature survey, decreases in real interests increase the inequality of income. 


\section{Data Set and Econometric Model}

\subsection{Data Set}

In this study, 5 developing countries, Turkey, Argentina, Brazil, India, Mexico, that are close to each other in terms of per capita income were analyzed. Panel data analysis technique was used with 85 observations for the period of 20002016 in these countries. In the analysis, the Gini coefficient was shown as "GINI" and real interest rates of the countries were shown as "RINTEREST". The data in the study were obtained from the database of World Bank, "databank.worlbank.org" and from the database of Harvard University, "dataverse.harvard.edu.tr".

\subsection{Econometric Model}

In this study, the effect of real interests on income distribution was examined. In the study, the Gini coefficient represents the dependent variable and real interest rate represents the independent variable. Estimated model (1) in the study is shown in the equation.

$\operatorname{GINI}_{\mathrm{it}}=\alpha_{0}+\alpha_{1}$ RINTEREST $_{\mathrm{it}}+\varepsilon_{\mathrm{it}}$

In this context, for the determination of cross sectional dependence in the series, CDLM test was used and thus, it was determined to use second generation panel unit root tests. Since the series are stable on different levels, short-term and long-term relationship between the two variables were determined with the ARDL model and then the VECM causality analysis was conducted.

\section{Evaluation of the Findings}

Cross sectional dependency decides which panel unit root tests to be used in order to prevent biased and inconsistent results of the analyses (Koçbulut ve Altıntaş, 2016:152). If there isn't cross sectional dependency in the series, first generation panel unit root tests and if there is a cross sectional dependency in 
the series, second generation panel unit root tests should be used. In this study, since there is a cross sectional dependency, second generation panel unit root tests were used. In Table 1, cross sectional dependency results for the GINI coefficient and real interests were given.

\section{Table 1: Cross Sectional Dependency for GINI Coefficient and Real Interests}

\begin{tabular}{|l|l|l|l|}
\hline \multicolumn{1}{|c|}{ Variable } & \multicolumn{1}{|c|}{ CD Test } & Test Statistic & Prob. \\
\hline GINI & CD $_{\text {LM1 }}$ (Breusch-Pagan LM) & 148.6118 & 0.0000 \\
\hline GINI & CD $_{\text {LM2 }}$ (Pesaran scaled LM) & 30.99453 & 0.0000 \\
\hline GINI & Bias-corrected scaled LM & 30.83828 & 0.0000 \\
\hline GINI & Pesaran CD & 2.530485 & 0.0114 \\
\hline RINTEREST & CD LM1 & \\
\hline RINTEREST & CD $_{\text {LM2 }}$ (Pesaran scaled LM) & 23.84931 & 0.0000 \\
\hline RINTEREST & Bias-corrected scaled LM & 23.69306 & 0.0000 \\
\hline RINTEREST & Pesaran CD & 116.6573 & 0.0000 \\
\hline
\end{tabular}

According to Table 1, there is a cross sectional dependency since the probability value for both variables are lower than 0.05 . Due to the determination of cross sectional dependency in the series, second generation panel unit root tests were used.

In this study, among second generation panel unit root tests, the CADF unit root test was used. The CADF test conducts unit root tests one by one for all of the sections in the series. That is, the CADF test conducts unit root test for the units. 
Furthermore, the CADF test gives consistent results whether the number of the observation in the analysis is lower or higher than the time dimension that is discussed. The mean of t-statistics values of the CADF tests present the CIPS test and it conducts unit root tests for all of the panel (Çiftçi et al., 2018:378; Sağlam et al., 2017:156-157). In this study, the CIPS values that presents the mean of the CADF test were given. In Table 2, unit root test results of the CADF were given.

Table 2: Unit Root Test Results of the CADF

\begin{tabular}{|l|l|l|l|l|l|l|}
\hline Variables & t-bar & cv10* & cv5* & cv1* & Z[t-bar $]$ & P-value \\
\hline RINTEREST & $\begin{array}{l}- \\
3.386\end{array}$ & 2.210 & 2.340 & 2.600 & 3.596 & 0.000 \\
\hline GINI & -1.882 & 2.210 & 2.340 & 2.600 & -0.331 & 0.370 \\
\hline$\Delta$ GINI & -3.101 & 2.210 & 2.340 & 2.600 & -2.976 & 0.001 \\
\hline
\end{tabular}

$*$ The series are significant on the significance level of $10 \%, 5 \%$ and $1 \%$.

According to Table 2, while the GINI coefficient is stable on the level of real interest, it includes unit root and it was made stable by subtracting the 1st difference. With the PMG estimator which is the Panel ARDL estimator that allows stabilities on different levels, coefficients will be estimated.

2 groups of estimators were developed by Pesaran et al. (1999) for the ARDL model. These are Mean Group Estimators and Pooled Mean Group Estimators. The PMG estimator allows differentiation in short-term coefficients (Pesaran et al., 1999:621). The PMG estimator is more advantageous than other estimators. The PMG estimator is used even though the series are stable on different levels and cointegrated on different levels. Furthermore, it pays attention to the cross sectional dependency and solves the problem of endogeny by taking delays. The PMG estimator allows heterogeneity in short-term coefficients and uses time series and means of countries that are in the panel while calculating the short- 
term coefficients (Topal, 2017:196). Due to these advantages, the PMG estimator will be used for the ARDL model. In Table 3, the PMG estimation results for the ARDL model were given.

Table 3: Panel ARDL Model Estimation (PMG)

\begin{tabular}{|l|l|l|l|l|}
\hline Variable & Coefficient & Std. Error & t-Statistic & Prob.* \\
\hline \multicolumn{5}{|c|}{ Long Run Equation } \\
\hline RINTEREST & 0.006575 & 0.000875 & 7.518118 & 0.0000 \\
\hline COINTEQ01 & -0.005506 & 0.002964 & -1.857853 & 0.0699 \\
\hline $\begin{array}{l}\text { D(GINI(-1)) } \\
\text { D(GINI(-2)) }\end{array}$ & 0.283377 & 0.182268 & 1.554727 & 0.1272 \\
\hline $\begin{array}{l}\text { D(GINI(-3)) } \\
\text { D(RINTEREST) }\end{array}$ & -0.000230 & 0.000530 & 0.433608 & 0.6667 \\
\hline $\begin{array}{l}\text { D(RINTEREST } \\
(-1))\end{array}$ & 0.000119 & 0.000379 & 0.314603 & 0.7546 \\
\hline $\begin{array}{l}\text { D(RINTEREST } \\
(-2))\end{array}$ & $-6.08 \mathrm{E}-05$ & 0.000518 & -0.117394 & 0.9071 \\
\hline $\begin{array}{l}\text { D(RINTEREST } \\
(-3))\end{array}$ & 0.000134 & 0.000297 & 0.449521 & 0.6553 \\
\hline
\end{tabular}

In Table 3, it can be seen that error term adjustment coefficient (COINTEQ01) is negative and significant on the significance level of $10 \%$. Thus, a deviation of 0.005 unit from the balance in short-term is balanced in long-term, that is, it 
can be stated that there is a long-term cointegration relationship between the variables. On the other hand, an increase of one unit in real interest rates, increases the Gini coefficient by 0.007 . Therefore, short-term coefficient is insignificant.

In the next phase, whether or not there is a causality between the real interests and the Gini coefficient, will be tested with the VECM (Vector Error Correction Model). In Table 4, the results for the VECM causality analysis were given.

\section{Table 4: The VECM Causality Analysis}

\begin{tabular}{|l|l|l|l|l|}
\hline Variables & Coefficient & Std. Error & t-Statistic & Prob. \\
\hline RINTEREST $\rightarrow$ GINI & -0.001690 & 0.000992 & -1.702472 & 0.0935 \\
\hline
\end{tabular}

In Table 4, the coefficient is negative and significant on the significance level of $10 \%$. This situation shows that there is a causality between the real interests and the Gini coefficient.

\section{Result}

Real interest which is the inflation-adjusted nominal interest, is an obstacle for the economic growth. Because, when the real interest rate is higher than the economic growth, it will cause the country to be in debt. Low real interests in the subjected countries and in Turkey point to high growth rate.

Income distribution demonstrates the distribution of national income which is produced in a country among the individuals or production factors. There are serious inequalities in the distribution of income in developing and underdeveloped countries. Unfair distribution of income is measured with Lorenz curve or with the Gini Coefficient which is obtained from Lorenz curve. The Gini coefficient is between 0 and 1 and as the index value approaches to 1 , unfairness increases and as it approaches to 0, income distribution becomes fairer. 
In this study, the effect of real interests on income distribution for the period of 2000-2016 in 5 countries (Turkey, Argentina, Brazil, India and Mexico) which are close to each other in terms of income per capita was tested with panel data analysis. Since there is a cross sectional dependency in the series, second generation panel unit root tests were used. In the CADF unit root test it was observed that the series are stable on different levels and the level of relationship was determined by using the ARDL method. For this, the PMG estimator, which allows cross sectional dependency and gives more consistent results compared to other estimators, was used.

According to the result of the study, while there isn't a short-term relationship between the variables, there is a cointegrated relationship in long-term. Furthermore, according to the PMG estimator, an increase of 1 unit, increases the Gini coefficient by 0.007 . Since the conducted causality analysis was resulted in accordance with the Gini coefficient from the real interests, it verifies this result. It is necessary to decrease real interests in order to provide fair distribution of income in the discussed country groups. Since the Gini coefficient would decrease as the real interests decrease, fair distribution of income would be provided and the inequality would be reduced. 


\section{REFERENCES}

Campbell, John Y. ve Mankiw, N. Gregory (1989), "Consumpiton, Income and Interest Rate: Reinterpreting the Time Series Evidence" NBER Macroeconomics Annual 1989, Volume 4, March 1989, pp.185-246.

Ceyhan, M.S. (2004). Faiz Dışı Fazla Nedir? Türkiye'de Mevcut Faiz Dış1 Fazla ve Reel Faizler ile Kamu Borçları Eritilebilir mi? (Muhtemel Senaryolara Göre Üç Projeksiyon). C. Ü. İktisadi ve İdari Bilimler Dergisi, Cilt 5, Sayı 2, 2004 , s.31-46.

Çalışkan, Ş. (2010). Türkiye'de Gelir Eşitsizliği ve Yoksulluk. Sosyal Siyaset Konferansları, Say1:59, 2010/2, s.89-132.

Çetin, Başak Işı1 (2013), İktisadi Sistemler Bağlamında Gelir Dağılımı-Kredi Ekonomisi

İlişkisi ve Türkiye, Çalışma ve Sosyal Güvenlik Eğitim ve Araştırma Merkezi Yayınlart,

Yayın No: 41, Ankara.

Çiftçi, İ., Özbek, R.İ. ve Uzgören, E. (2018). Feldstein-Horioka Bulmacasının OECD Ülkeleri İçin Panel Veri Analiziyle Sınanması. Yönetim ve Ekonomi, Cilt:25, Say1:2, s.369-390.

Demir, M. ve Sever, E. (2008). Kamu İç Borçlanmasının Büyüme, Faiz ve Enflasyon Oranı Üzerindeki Etkileri. Elektronik Sosyal Bilimler Dergisi, Yaz2008 C.7 S.25 (170-196).

Ersezer, D. (2006). Gelir Dağılımı Politikası ve Araçları. Fırat Üniversitesi Sosyal Bilimler Dergisi, Cilt:16, Sayı:1, s. 255-268.

Grüner, Hans Peter (2001), "Wealth Distribution and Interest Rates: Empirical Evidence For The US" CEPR Discussion Paper 3106. Review of Economic Studies, Vol. 71, pp.1001-1026. 
Kamac1, A. (2016). Seçilmiş OECD Ülkelerinde Reel Ücret, Enflasyon ve Reel Faizlerin İşgücü Verimliliği Üzerine Etkisi: Panel Veri Analizi. Bartın Üniversitesi İ̈BF Dergisi, Cilt:7, Sayı:14, s.321-340.

Koçbulut, Ö. ve Altıntaş, H. (2016). İkiz Açıklar ve Feldstein-Horioka Hipotezi: OECD Ülkeleri Üzerine Yatay Kesit Bağımlılığı Altında Yapısal Kırılmalı Panel Eşbütünleşme Analizi. Erciyes Üniversitesi İktisadi ve İdari Bilimler Fakültesi Dergisi, Say1: 48, Temmuz-Aral1k 2016 ss. 145-174.

Lancastre, M. (2016). Inequality and Real Interest Rates. MPRA, Paper No: 85047, March 2016.

Maraşl1, O. (2016). Interest And Social Justice: The Impact Of Real Interest Rate On Income Inequality. Íslam Ekonomisi Ve Finansı Dergisi, Vol. 1, pp.77118.

Pesaran, M.H., Shin, Y. ve Smith, R.T. (1999). Pooled Mean Group Estimation of Dynamic Heterogeneous Panels. Journal of the American Statistical Association, Vol. 94, No. 446 (Jun., 1999), pp. 621-634.

Sağlam, Y., Egeli, H.A. ve Egeli, P. (2017). Gelişmiş ve Gelişmekte Olan Ülkelerde Ar\&Ge Harcamaları ve Ekonomik Büyüme Arasındaki İlişki: Panel Veri Analizi. Sosyoekonomi, Vol.25 (31), s.149-165.

Saymeh, Abdülaziz Farid ve Orabi, Marwan Mohammad Abu (2013), "The Effect of Interest Rate, Inflation Rate, GDP On Real Economic Growth Rate In Jordan" Asian Economic and Financial Review, 2013, 3(3):341-354.

Sever, Erşan ve Mızrak, Zekeriya (2007), "Döviz Kuru, Enflasyon Ve Faiz Oranı Arasındaki İlişkiler: Türkiye Uygulaması" SÜ IİBF Sosyal ve Ekonomik Araştırmalar Dergisi, Sayı:13, s.265-283.

Shrivastava, A.; Behera, H.K., Kavediya, R. ve Das, A. (2013). Real Interest Rate impact on Investment and Growth - What the Empirical Evidence for India Suggests. 
https://rbidocs.rbi.org.in/rdocs/Publications/PDFs/IDGSR08082013.pdf Access:01.02.2019

Sugözü, İ.H., Erdoğan, S. ve Ulaşan, E. (2017). The Impacts Of Interest Expenditure on Income Distribution and An Application on The Factors Distorting Income Distribution: An Empirical Analysis For Turkey. Turkish Studies, Volume 12/12, p. 231-250

Topal, M.H. (2017). Vergi Yapısının Ekonomik Büyüme Üzerindeki Etkisi: OECD Ülkelerinden Ampirik Bir Kanit. Siyaset, Ekonomi ve Yönetim Araştırmaları Dergisi, Temmuz 2017, Cilt:5, Sayı:3, s.183-206.

Yurttagüler, İ.M. ve Kutlu, S. (2013). Reel Faiz Oranının Uzun Hafiza Modeli ile İncelenmesi: Türkiye Örneği. Maliye Dergisi, Sayı:164, Ocak-Haziran 2013, s.208-219. 